\title{
Patents Go to The Market? University-Industry Technology Transfer from a Brazilian Perspective
}

\author{
Laís Viana ${ }^{1 *}$, Danilo Jabour ${ }^{1}$, Paulina Ramirez $z^{2}$ Gustavo da Cruz ${ }^{1}$
}

\begin{abstract}
The purpose of this paper is to explore the TT between university-industry from a Brazilian perspective, with special reference on the university Intellectual Property - IP and TT legal instruments. The methodology was designed on a quantitative approach aiming to provide a better understanding of the problem. Secondary data collection was performed through documentary analysis that aims to identify and quantify the variables related to patents, licensing and TT agreements. Later, data are grouped, classified and treated, which allowed inference and interpretation. The results show that the TT between university-industry is in an embryonic stage in Brazil, even if occurred a considerable increase of IP required over the last few years. In this context, it is possible to affirm that the academic research outcomes are not being absorbed in an effective way by the industries, and, as a consequence, just an insignificant percentage of the patents go to the market.
\end{abstract}

Keywords: technology transfer; university-industry; brazilian universities; TTO; Innovation.

Submitted: April 24 $4^{\text {th }}, 2018$ / Approved: July $5^{\text {th }}, 2018$

\section{Introduction}

The role of university has become very dynamic and challenging in the last three decades, considering that the university is expected to assume a more active role in the regional and national economic development (Piirainen, Andersen, \& Andersen, 2016). This necessary change and new alignment with environmental and economic demands of society occurred mainly in reason of the knowledge has become the most significant source of innovation (Anatan, 2015; Pausits, 2015).

This slow but continuous process of changing has created a new mission for universities in addition to traditional teaching, research and extension activities (Ranga \& Etzkowitz, 2013). This third-mission refers to all activities related to the generation, use, application and exploration of the academic research outcomes aiming to benefit the society, through the application of scientific principles to solve practical problems (Molas-Gallart \& Castro-Martínez, 2007; Wahab, Rose, \& Wati, 2012)

Etzkowitz (1998) and Siegel, Veugelers, and Wright (2007) mentioned that the third-mission activities might also be called Technology Transfer - TT, with focus on a dimension of interaction and commercial exploration of academic research outcomes. It is also an opportunity to continue the opening of the universities through exchanges with the outside of the scientific system to find real answers to social issues (Pausits, 2015).

Shane and Venkataraman (2007) point that there is a strong link between academic research outcomes, innovation industries and social benefits. Despite of it, this relationship is not a linear process. It has interference from the historical development of countries and regions, as well as a number of industry and firm-specific factors (Ramirez, Love \& Vahter, 2013).
Current researches (Phan \& Siegel, 2006; Clarysse, Tartari, \& Salter, 2011; Perkmann et al., 2015) have shown that TT between universityindustry can generate innumerous benefits to society by promoting industrial competitive advancement and consequently improves regional economic development. In addition to generating this benefits, Markman, Gianiodis, Phan, and Balkin (2005) argue that the TT is actively used in many universities to maximize rents and generate a large amounts of profits, as well as build relations with external stakeholders (Link, Siegel, \& Bozeman, 2007).

Nevertheless, the TT process is only successful if the new technology is used by society (Fontana, Geuna, \& Matt, 2006). In other words, it is when new ideas are raised from academic research outcomes becoming a concrete product ready to go to the market (Shane, 2002; Warren, Kitagawa, \& Eatough, 2010).

In this context, there is a growing international attention to the importance of innovation generated by university-industry relationships (Siegel et al., 2007). Consequently, governments in many developed and developing countries are encouraging universities to improve innovation activities through policies designed to promote and maintain university-industry interaction. It is the goal of improving the capacity to generate and transfer new technologies based on knowledge and skills of these organizations (Wahab et al., 2012; Ranga \& Etzkowitz, 2013). Despite these efforts, TT processes are in the early stages in a number of developing countries, especially compared to other countries such as the UK and the USA (GII, 2015).

The purpose of this paper is to explore the TT between universityindustry from a Brazilian perspective, with special reference on the university Intellectual Property - IP and TT legal instruments. The core argument is that universities produce several patents and other IP assets but do not license or use other legal instrument for commercialization to industries, on which it is evident that the process in Brazil is still embryonic.

(1)Santa Cruz State University, Ilhéus, Bahia, Brazil.

(2)University of Birmingham, Birmingham, UK

*Corresponding author: laisviana.adv@gmail.com 
Despite growing interest in university-industry interaction to explain and to justify the process of the TT processes, there are insufficient theoretical and empirical evidence on the commercialization of research and technology across the organizations (Markman et al., 2005; Link et al. 2007; Mowery \& Ziedonis, 2015; Anatan, 2015), with many unsolved managerial and policy issues (Phan \& Siegel, 2006).

Several studies have been focused on patents (Geuna \& Nesta, 2006; Crespi, D'este, Fontana, \& Geuna, 2011; Walter, 2016; Verhoeven, Bakker \& Veugelers, 2016) and license (Thursby, Jensen, \& Thursby, 2001; Kim \& Vonortas, 2006; Macho-Stadler, Perez-Castrillo \& Veugelers, 2007; Mowery \& Ziedonis, 2015), unfortunately there is a limited number of researches available that analyses the relationships between patents-license on commercialization process of universityindustry, specally in Brazil.

The methodology of this paper was designed on a quantitative approach aiming to provide a better understanding of the problem. In order to build a theoretical framework consistent with the theme, the bibliographic review was directed to the main international databases for subsequent tabulation through analytical and interpretative reading. Secondary data collection was performed through documentary analysis that aims to identify and quantify the variables related to patents, licensing and TT agreements. These data were obtained foremost in documents from the Intellectual Property Policy of the Scientific and Technological Institutions Forms of Brazil - FORMICT, Ministry of Science, Technology and Innovation Reports - MCTI, Global Innovation Index Results - GII and World Intellectual Property Organization Reports - WIPO. Later, data are grouped, classified and treated, which allowed inference and interpretation.

This paper is organized in the follow way: Section 2 presents a discussion of the literature review of Technology Transfer. The section 3 and 4 are focused on the University-Industry Technology Transfer and Technology Transfer Commercialization framework. Furthermore, the section 5 refers to the imminence of patents to go to the market. The section 6 is presented and explains the highlights of the IP and TT in a Brazilian Perspective. Section 7 presents the conclusions with limitations of research and directions for further researches.

\section{Technology Transfer}

The Roman Empire at the height of territorial expansions has already developed TT with the conquered countries, not only in matters of military infrastructure, essentially for logistics achievements, but also in fields such as agriculture, medicine, arts and philosophy (Holt, 1990; Greene, 1994). Many years have passed, it is only in the early 80s a number of policy initiatives and incentive programs were created in the United States and major European countries, focused on research, technologies and mechanisms to improve the TT (Bozeman, 2000).

TT is not just a transmission of knowledge from one country to another, it is a transfer process of any type of scientific findings from one organization to another addressed to expand the innovation capacity (Chapple, Lockett, Siegel, \& Wright, 2005; Audretsch,
Lehmann, \& Wright, 2014). However, TT is not just a movement or delivery innovation, it is a dynamic, complicated and a transdisciplinary process whose success owes to factors coming from other sources (Jafari, Akhavan, \& Rafiei, 2014). Besant and Rush (1993) elucidated that it involves any type of activities and processes through the incorporated products, processes or knowledge which are passed from one user to another.

Bukala (2008) and Gervais, Marion, Dagenais, Chiocchio, and Houlfort (2016) argue that the TT is a combination of activities that requires multidimensional approach and interaction instruments between two or more organizations during a knowledge or technical producing process to create a new product or service. Cruz and Bezerra (2017) add that the TT must be understood as the process of dissemination and exchange of information, matching technology with needs and creative version of items with new applications.

The dynamic nature of TT has contributed to the appearance of many definitions and conceptions (Anatan, 2015). Nevertheless, the conceptualization of TT refers to use, mobilization, application, exchange, development and management related to a product, service, technology and knowledge. (Reddy \& Zhao, 1990; Etzkowitz \& Leydesdorff, 1998; 1999; Chapple et al., 2005; Phan \& Siegel, 2006; Ranga \& Etzkowitz, 2013; Audretsch et al., 2014).

The extent of the definition demonstrates the complexity and diversity of TT fieldwork. It resultes from dynamic elements in cross-institutional activities and relationships between individuals and organizations that may have different points of view about the value and potential use of technology, creating distinct interfaces very often chaotic and disorderly (Etzkowitz \& Leydesdorff, 1998; Bozeman, 2000).

In fact, the TT processes are nonstop reshaping in an endless transition with four interfaces possibilities between organizations, which involves: industry-industry, university-industry, government-government and university-government. However, the relation between university-industry is generally the major player in the innovation process, producing an important relationship between science and technology (Etzkowitz, \& Leydesdorff, 2000; Dooley \& Kirk, 2007; Schaeffer, Dullius, Maldonado, \& Zawislak, 2015).

Nevertheless, one of the best ways to promote the innovation country capacity is through university-industry interactions, where the university carries out the TT from academic research outcomes to industries that previously were unaware of them, to put into operation new products or processes of transformation, or manufacturing (OECD, 2007).

\section{University-Industry Technology Transfer}

For a long period, universities and industries have been focused on their own traditional functions, closed in their bubbles and in their strongly defended boundaries (Etzkowitz, 1998). However, both (university-industry) recognized the mutual benefit that can be gained through collaboration on discovery research in the innovation 
process to confront the high complex and turbulent environments that occurred in the last two decades (Dooley \& Kirk, 2007; Gunsel, 2015).

According to Audretsch et al., (2014), university-industry relationships are essential to create new connections between science and technology. Nowadays academic research and industrial innovation become increasingly important in countries and regions at various stages of economic development (Schaeffer et al., 2015; Ramirez et al., 2013)

Schaefer et al. (2015) add that the University Industry Technology Transfer - UITT is a fundamental activity for the application of scientific knowledge in the production sector, which stimulates and influences the innovation processes in both organizations. As a result, Geuna and Muscio (2009) point that many universities are trying to promote UITT with new mechanisms to be successful in the third mission activities.

In today's world there are several formal UITT mechanisms, which include, but it is not limited to: collaborative research, joint ventures research, technology consulting, strategic alliances, licensing and acquisition, spin-off companies and incubators (Markman et al., 2005; Link et al., 2007, Muscio, Quaglione, \& Vallanti, 2014; Ranga et al., 2016).

On the other hand, the informal TT includes, but it is not limited to: meetings, conferences, communication processes, publications, reports, undergraduate courses at university, consulting, recruiting former graduate students, $\mathrm{PhD}$ supervision and ad hoc advice (Hertzfeld et al., 2006; Phan \& Siegel., 2006; Geuna \& Muscio., 2009; BodasFreitas, Geuna, \& Rossi, 2011; Bollin \& Ericksonn, 2016).

For university-industry establish and sustain collaboration, they must gain mutual benefit from these interactions (Dooley \& Kirk, 2007), however until 80s the knowledge or even physical product developed at universities were mostly informally transferred in an one-way course to industries that were benefited with the gains from this new technology, with nothing addressed to the universities (Markman et al., 2005; Perkmann et al., 2013). Even though it has been almost 40 years, this unfortunate situation still exists today in many developing countries according to international statistics (GII, 2015).

In this context, Bodas-Freitas et al. (2011) argued that the UITT process must be formal, supported by legal instruments signed between the parties, respecting the division of work and the rules for joint decisions and actions. Thereby providing safeguard of university's IP, such as a patent or any other protected asset, is a disposition to allow some kind of exploration from industries partners with mutual benefit (Thursby et al., 2001; Link et al., 2007).

Bodas-freitas et al. (2011) research has shown that the diversity of the industrial sectors and the geographical proximity between universityindustry provides a formal UITT with interconnections and interdependent process (Perkmann et al., 2013) able to produce innumerous benefits to society by promoting the advancement of the industrial competitivity and consequently improving of the national and regional economic growth.
Beyond the advance in the competitivity and the economic development, the UITT allows researchers to conduct a better basic research and it gives them a different perspective, which can sometimes be the inspiration for innovative researches (Geuna \& Muscio, 2009). In fact, the interaction between university-industry does not only mean transferring knowledge from producer to buyer, it works in both directions.

Briefly, this multi-stage process includes: research, disclosure, patenting, licensing and commercial use (Link et al., 2007). Although all these steps are important, to be successful in UITT the commercialization stage must be done in a way that the academic research outcomes could go to the market.

\section{Technology Transfer Commercialization}

The term "transfer" added to "technology" usually results in a process of "selling" such technology (Zhao \& Reisman, 1992). For this reason, the term Technology Transfer Commercialization - TTC is found in several studies (Siegel, Waldman, Atwater \& Link., 2003; Siegel et al., 2007; Chapple et al., 2005; Markmann et al., 2005; Perkmann, 2013; Geisler \& Turchetti, 2015; Mattila \& Lehtimaki, 2016).

According to Geisler and Turchetti (2015), the goals of TTC is to generate a process where academic research outcomes play a useful role in society, through the introduction of a new idea, a technological solution, a product, a service, a procedure, a policy, an organizational form or a firm to the market (Link et al., 2007; Mattila \& Lehtimaki, 2016).

In the last two decades, the TTC activities have become increasingly important on the role of universities, particularly in the setting of a direct source of funds derived from TTC transactions and as a means of acquiring visibility and legitimacy in the research field (Bodas-Freitas et al., 2011; Pausits, 2015; Piirainen et al., 2016) with the objective to obtain financial benefits (Perkmann et al., 2013).

Phan and Siegel (2006) argue that TTC can potentially result in financial benefits for the universities. It happens mainly when the universities are interested in maximizing their social return on public investment in research and in the effort to improve their self-sustenance (Gervais et al., 2016), creating revenue, which is typically reinvested in academic research (Chapple et al., 2005).

To support commercialization activities, many universities have established the Technology Transfer Offices - TTOs, Science Parks and Incubators to create supportive internal rules and procedures for exploration of academic research outcomes and resources (Siegel et al., 2003; Clarysse et al., 2011). This infrastructure is significant not only for an inclusion of a marketing support, but also for its ability to enhance the commercialization of academic knowledge (Etzkowitz, 2003; Perkamnn et al., 2013).

Once the patent has been granted, the TTO must carry out four activities in order to succeed the commercialization of the technology. 
The first activity involves the measuring of operational and economic viability of this patent. The second is the mapping of industries or entrepreneurs, identifying potential stakeholders with financial support conditions. The third activity is the conducting of the negotiation meetings with the selected industries for define the agreements of licensing or other protected IP. In the fourth and final phase, the technology is converted into a commercialized product (Siegel et al., 2003; Markman et al., 2005).

Consequently, commercialization is related to all university activities that are involved in achieving a new technology or any finding resulting from academic campus and the attempt to incorporate these results into the market (Geuna \& Muscio, 2009). The key of UITT is to make their findings marketable (Audretsch et al., 2014), nevertheless, universities, industries and other players cannot succeed without boundary-spanning activities in the organizations involved (Taheri \& Geenhuizen, 2016).

Unfortunately, managing the TTC process is a serious challenge. It can be painful and difficult to achieve (Wright, Birley \& Mosey, 2004; Ambos, Mäkelä, Birkinshaw, \& d'Este, 2008). It may become a chaotic and disorderly process involving groups and individuals who may hold different views about the value and potential use of the technology (Bozeman, 2000). This unsuccessful situation occurs because of the mix of factors that adversely affect the process, which include, but are not limited to: public policy, commercial network, financial incentives, involvement, bureaucracy and culture are factors that interfere in the TTC process (Siegel et al. 2003, Geisler \& Turchetti, 2015).

Despite evidence of some improvement in the commercialization process in the last years (Perkmann et al., 2013; Geisler \& Turchetti, 2015; Mattila \& Lehtimaki, 2016), there is still an enormous gap between universities and industries to ensure that patents become licensed, and posteriorly a product in the market.

\section{Patents go to the market}

Until nowadays, the universities are still called "ivory tower", a metaphor of isolation from market or government influence that refers to the academic impenetrable boundaries (Thursby et al., 2001; Taheri \& Geenhuizen, 2016). In this context, conducting boundary-spanning between university-industry may be the most difficult challenge in the UITT (Wright et al., 2004; Perkmann \& Schildt, 2015).

Consequently, it is also important to note that analyze and understand the process of technology transfer from universities into marketable ideas became one of the most important topics in academic research (Audretsch et al., 2014). Bozeman (2000) argue that the definition of UITT sometimes create conflicts due to different references involved. However, one thing is certain: it will succeed when the technology is introduced into the market with a purpose for further use and commercialization (AUTM, 2002; Geuna \& Muscio, 2009).

In this context, patents assume a protagonist role in the transformation of knowledge and technology into marketable products
(Etzkowitz, 1998). Then license has become the most popular mechanism of universities commercialization (Muscio et al., 2014). In addition, Phan and Siegel (2006) argue that UITT can potentially result in financial gains for the university and job creation in the local region. According to Perkmann et al. (2013), in the past many universities have passively licensed their technologies, nowadays most have actively created ways for commercialization mechanism. This is the reason why in the last decades, numerous countries promoted policies, programs and institutional structures, which gave to the universities the right to retain title and license inventions (Thurbsy et al., 2001; Ranga et al., 2016).

To improve competitive advantage in the fast-changing global economic environment (Burhanuddin, Arif, Azizah, \& Prabuwono, 2009), industries are forcing the innovation processes to become more open and distributed, considering the growing importance of scientific knowledge in technological change and their role in economic development (Ramirez et al., 2013). The result has been the reshapes of the Research and Development (R\&D) industries and the universities goals towards a TT that require new institutional arrangements and alignments (Etzkowitz \& Leydesdorff, 1999; Siegel et al., 2003). Nevertheless, Kim and Vonortas (2006) argue that there is an extensive evidence of the increasing use of licensing agreements in the industries.

Even though the UITT looks like an easy process, many attempts have been unsuccessful. Previous studies (Wright et al., 2004; Bekker \& Bodas-Freitas, 2008; Bozemann, 2000; Crespi et al., 2007; Gervais et al., 2016; Markman et al., 2008; Perkmann et al., 2013; Wallin et al., 2014) demonstrated that some technologies have difficults to achieve the market.

Furthermore, Muscio et al. (2014) consider that there is a gap in the connection between university and nonacademic institutions, because some researches have no impact in the local economic development and in the industry competitive advantage (Anatan, 2015; Guan, Mok, Yam, Chin \& Pun, 2006). As a result, to be effective in the third mission, the universities need to improve their technology transfer process to create a positive impact in the society and a competitive advantage in the industries.

\section{Brazilian Perspective}

Economically, Brazil is considered one of the major developing countries with enormous potential for industrial development, domestic demand and innovation capacity. However, it is essential to improve the country's innovation and technological fieldwork through the modernization of infrastructure, consolidation of investment funds, attraction and retention of human resources and promotion of technological innovation at universities and industries (MCTI, 2016).

Brazil is considered a continental country divided in five regions: north, northeast, center-west, south and southeast, having a total of 200 million inhabitants living in an enormous economic-regional inequality with a cultural diversity between the regions mentioned above (IBGE, 2016). Since the sugarcane cycle in the seventeenth 
century, passing through the mining and coffee economies in the nineteenth and the process of industrialization in the 20th century, the five regions of Brazil have always presented different levels of economic development, with a concentration of production and income in the Southeast region (Casali, Silva \& Carvalho, 2010).

The Brazilian diversity among the regions is not just a reflection of economic development inequality, but it is also related with the development of education, technical training and university infrastructure. Brazil has 195 universities, mostly in the Southeast region with 78 universities, followed by the south with 47 , the northeast with 39 , the north with 17 and the center-west with 14 (IBGE, 2016). Despite of that, just 18 universities in Brazil have an international level according to the 1.000 best universities world ranking Center for World University Rankings (CWUR, 2017).

In this context, it can be noticed that regional development has a direct influence on the educational level in Brazil and on the development of universities, which explains the fact that Brazil has some universities that are so developed and others with a high disability index. It reflects directly on the innovation and technology transfer rates discussed in this article.

In order to maximize the innovation capacity in Brazil, the Innovation Law was created in 2004, establishing among others features, the reinforcement of the Research Institutions - RIs, composed mostly of universities, technological institutions, research centers and technological parks. To better understand this innovation progress, the Ministry of Science, Technology and Innovation - MCTI has published annual reports, called FORMICT.

The 2007, 2008 and 2009 reports presented a superficial analysis of the national panorama, with a punctual and disordered IP and TT data. Despite 2010 FORMICT reports began to be published with a large range of data, the data are still statics nowadays. As a result, this article is mainly focused on the classification, grouping and treatment of the data from 2010 to 2014 editions of the report, with the purpose of making inferences and more qualified interpretations, as presented below. There is no data available referring to 2015 and 2016 editions at the time of the production of this article.
In 2010, there were 164 RIs identified, increasing to 176, 193, 261 and 264 between the years 2011 and 2014. In this period, there was a $62 \%$ increase due to the democratization and expansion of higher education policies implemented in Brazil, in response to the low number of graduate students in the country as well as the centralization of universities located mostly in regions with higher GDP (Cruz \& Santos, 2017). It should be noted that most of the universities are public, federal level and located in the Southeast, Northeast, South, Center-West and North regions, respectively. This differentiation between these regions shows that the most developed regions with higher concentration of income can have better expressive numbers of TT, besides that the universities located in these regions have more experience considering that they were created it has been a long time and they also have access to resources, concentration of industries and universities and infrastructure. The Southeast region, the most economically developed region, concentrates $70 \%$ of the costs of developing technologies carried out by Brazilian industries (Casali et al., 2010).

However, there was also a superior involvement by some RIs with the innovation field, outstanding the implementation of the Innovation Law which aims to stimulate technological innovation and R\&D activities through financial incentives for projects of scientific and technological research carried out with partnerships between university and industry in Brazil (MCTI, 2016).

The implementation of TTOs in RIs also showed a growth. In 2010, $57 \%$ of the RIs had a TTO implemented, followed by $66 \%, 73 \%, 64 \%$ and $68 \%$ in the subsequent years. The findings between 2010 and 2014 have a modest growth, equivalent to $11 \%$ in 5 years.

Nevertheless, the Innovation Law establishes that all public RIs have their own TTO or are associated with other institutions with the purpose of promoting the IP and TT fields (Brazil, 2016). This modest growth rate probably occurs due to the discontinuation of financial support funds for scientific research, the lack of technical training and the inadequate way of human resources contracting to manage TTOs, since the most universities in Brazil are public (Torkomian, 2009).

Table 1. Brazilian RI Evolution

\begin{tabular}{|c|c|c|c|c|c|c|}
\hline VARIABLES & & 2010 & 2011 & 2012 & 2013 & 2014 \\
\hline RI researched & & 164 & 176 & 193 & 261 & 264 \\
\hline RI with TTO & & $57 \%$ & $66 \%$ & $73 \%$ & $64 \%$ & $68 \%$ \\
\hline TTO with filed patents or other IP requests & & $61 \%$ & $65 \%$ & $69 \%$ & $56 \%$ & $61 \%$ \\
\hline \multirow{2}{*}{ Patents and other IP } & Filed & 1078 & 1595 & 1769 & 1901 & 2163 \\
\hline & Granted & 169 & 208 & 207 & 271 & 350 \\
\hline \multirow{3}{*}{$\begin{array}{l}\text { Filed patents and other } \\
\text { IP requests by applicant country }\end{array}$} & Brazil & $90,9 \%$ & $91,7 \%$ & $90,3 \%$ & $91,7 \%$ & $93,7 \%$ \\
\hline & Foreign countries & $6,8 \%$ & $8,0 \%$ & $8,4 \%$ & $8,0 \%$ & $6,1 \%$ \\
\hline & Brazil + Foreign countries & $2,3 \%$ & $0,3 \%$ & $1,3 \%$ & $0,3 \%$ & $0,2 \%$ \\
\hline \multirow{3}{*}{$\begin{array}{l}\text { Granted patents and other } \\
\text { IP by applicant country }\end{array}$} & Brazil & $85,8 \%$ & $90,9 \%$ & $80,2 \%$ & $90,8 \%$ & $92,6 \%$ \\
\hline & Foreign countries & $13,0 \%$ & $8,2 \%$ & $19,8 \%$ & $8,9 \%$ & $71,0 \%$ \\
\hline & Brazil + Foreign countries & $1,2 \%$ & $1,0 \%$ & $0,0 \%$ & $0,4 \%$ & $0,3 \%$ \\
\hline RI with TT agreements/contracts & & $22 \%$ & $25 \%$ & $23 \%$ & $17 \%$ & $18 \%$ \\
\hline
\end{tabular}

$\mathrm{RI}=$ Research Institutions. TTO= Technology Transfer Office. IP= Intellectual Property. TT=Transfer Technology 
In this context, in 2010 there were $61 \%$ RIs with patents filed or other IP requests, reaching 65\% in 2011, 69\% in 2012, 56\% in 2013 and $61 \%$ in the year 2014. The findings have a little rate fluctuations over the years with a zero increase between 2010 and 2014. The number of RIs with patents filed or other IP requests is very low and stagnant over the 5 years. Outstanding the excess of bureaucracy, difficult alignments among the Brazilian legislations, inexpressive integration between institutions and researchers, and a low funding in R\&D from industries (Fujino \& Stal, 2007). Mazzucato (2016) considers that demand for knowledge produced by university-industries partnerships is very low in Brazil.

In 2010, Brazil had 1078 patent applications or other IP requests, increasing to $1595,1769,1901$ and 2163 in the following years. There has been a significant growth in the number of requests between 2010 and 2014 , reaching more than $100 \%$ in 5 years. It is maybe a reflex of the government programs established to support and strengthen the TTOs by expanding the universities physical structure, improving the quality technical support and in the consolidation of the IP protection culture in Brazil (MCTI, 2016). In this context, Mazzucato (2016) believe that the Brazilian scientific research field has improved substantially in recent decades.

However, when comparing the filed and granted patent or other IP, the findings present an inexpressive number of granted, with an average of $13 \%$ along the years, in which only 169 were granted in 2010, 208 in 2011, 207 in 2012, 271 in 2013 and 350 in 2014. This very low rate is probably linked to the INPI's (National Institute of IP) delay in granting a patent application in Brazil, which currently takes 12 years on average, or even the failure to analyze the patent application by the TTOs when examining the patentability requirements (Torkomian, 2009).

Most of the applications, $90.9 \%, 91.7 \%, 90.3 \%, 91.7 \%$ and $93.7 \%$, respectively between 2010 and 2014 were made in Brazil. Applications in foreign countries are still very low with $6.8 \%, 8.0 \%, 8.4 \%, 8.0 \%$ and $6.1 \%$, over the years. The patent or other IP filed in Brazil along with foreign countries has a decrease over the 5 years, representing $2.3 \%$ in $2010,0.3 \%$ in $2011,1.3 \%$ in $2012,0.3 \%$ in 2013 and $0.2 \%$ in 2014 . Consequently, the patent granted are mostly in Brazil, with $85.8 \%$ in 2010 , followed by $90.9 \%, 80.2 \%, 90.8 \%, 92.6 \%$ in the following years, presenting an average of $80 \%$ between the years 2010 to 2014 . The protection granted in foreign countries is median, with $13.0 \%$ in 2010 , followed by $8.2 \%, 19.2 \%, 8,9 \%$ and $7.1 \%$ in 2014 . The protection granted in Brazil along with foreign countries are inexistent, with $1.2 \%, 1.0 \%, 0.0 \%, 0.4 \%, 0.3 \%$, respectively, representing $0.5 \%$ between 2010 and 2014 .

This situation may be explained by the low quality of the TTOs human resources, the lack of interest from researchers to protect their inventions abroad, the excess of bureaucracy in Brazilian legislation, the high cost of filing an international patent application and the low investment of innovation industries in foreign countries. This statistic reflex the low internationalization of Brazilian universities and industries, which directly affects Brazil's ranking global innovation index
(Torkomian, 2009; Fujino \& Stal, 2007; Kenny \& Mowery, 2014). The findings have a very low number of RIs with TT agreement, with $22 \%$ in $2010,25 \%, 23 \%, 17 \%$ and $18 \%$ in the following years, representing $21 \%$ among 2010 to 2014 . This is a reflex of the inexpressive patents granted to universities and a weak partnership between university-industry despite the increasing number of TTOs implemented and patents filed over the 5 years.

The number of TT agreements between university-industry is very shy, which only $18 \%$ of RI had some of it in 2014. It shows that the TT processes is in embryonic stage in Brazil, considering that the innovation culture in many universities and industries around the country still need to be established. Fujino and Stal (2007) add that the TTOs in Brazil have not yet achieved a level of autonomy and infrastructure adequate to the operation of a licensing policy.

According to the Brazilian legislation, there are several TT legal instruments for universities that allows the industries to explore or use their patents or other IP assets, that include but it is not limited to: licensing agreement, R\&D partnership agreement, know-how and technical assistance contract, share agreement of equipment, laboratories, materials and other facilities, non-disclosure agreement, co-ownership contract and biological material transfer (MCTI, 2016). The statistics of Brazilian TT legal instruments were published in 2011 for the first time by MCTI. Before that there is no official data available. The most common TT legal instrument is the licensing agreement, representing $77.3 \%$ in 2011 , followed by $76.1 \%, 64.1 \%$ and $63.6 \%$, respectively. There was a decrease over the 4 years associated by the previously issues discussed in the article.

Table 2. TT Legal Instruments between Brazilian University-Industry

\begin{tabular}{lcccc}
\hline $\begin{array}{l}\text { TT LEGAL INSTRUMENTS BET- } \\
\text { WEEN UNIVERSITY-INDUSTRY }\end{array}$ & $\mathbf{2 0 1 1}$ & $\mathbf{2 0 1 2}$ & $\mathbf{2 0 1 3}$ & $\mathbf{2 0 1 4}$ \\
\hline Licensing agreement & $77,3 \%$ & $76,1 \%$ & $64,1 \%$ & $63,6 \%$ \\
\hline R\&D partnership agreement & $7,0 \%$ & $10,4 \%$ & $7,5 \%$ & $17,5 \%$ \\
\hline $\begin{array}{l}\text { Know-how and technical assistance } \\
\text { contract }\end{array}$ & $2,2 \%$ & $0,9 \%$ & $9,0 \%$ & $8,9 \%$ \\
\hline $\begin{array}{l}\text { Share agreement of equipment, labo- } \\
\text { ratories, materials and others facilities }\end{array}$ & $1,5 \%$ & $2,3 \%$ & $0,3 \%$ & $1,3 \%$ \\
\hline Non-disclosure agreement & $0,0 \%$ & $0,0 \%$ & $3,6 \%$ & $4,4 \%$ \\
\hline $\begin{array}{l}\text { Co-ownership contract } \\
\text { Biological material transfer }\end{array}$ & $4,4 \%$ & $3,6 \%$ & $4,5 \%$ & $3,4 \%$ \\
\hline \begin{tabular}{l} 
Other agreements/contracts \\
\hline
\end{tabular} & $2,7 \%$ & $5,5 \%$ & $10,8 \%$ & $0,5 \%$ \\
\hline
\end{tabular}

The R\&D partnership agreement is another type of TT legal instrument very similar to the licensing agreement, but in this case, there is a participation of a public institution in the TT process (Pimentel, 2010). The findings present $7.0 \%$ in 2011 with an increase to $10.4 \%$, $7.5 \%$ and $17.5 \%$ in the following years. It shows a little progress in the relationship between private and public institutions in Brazil. 
The Know-how contracts are another kind of TT legal instrument that aim to obtain knowledge and techniques not protected by property rights, destined to the production of industrial goods and services (INPI, 2016). The rate of know-how, technical assistance and other services contracts are low, with a $2.2 \%$ in 2011 , followed by $0.9 \%$ in $2012,9.0 \%$ in 2013 and $8.9 \%$ in 2014. Despite the little growth over the years, there are a few contracts for know-how, technical assistance and other services, especially when compared to developed countries.

Share agreement of equipment, laboratories, materials and other facilities are another type of TT legal instrument that allowed industries to use RIs laboratories and equipment in a joint innovation process (Pimentel, 2010). The findings are quite inexpressive, with $1.5 \%$, $2.3 \%, 0.3 \%$ and $1.3 \%$ over the years. In 2013 , there is a larger drop related to the low number of research project performed between university-industry.

Non-disclosure agreements provide an obligation to not disclose scientific or technological data, information or knowledge, restricting the access to this information only to people expressly authorized by the parts of the project execution, on which the terms are fixed by several clauses (Pimentel, 2010). There are no findings in 2011 and 2012, registering only $3.6 \%$ in 2013 and $4.4 \%$ in 2014 . It showss the low concern of TTO researchers and officials about the importance of signing a confidentiality agreement aiming to protect information from UITT partnerships against undue disclosure to other organizations.

Co-ownership agreements are a TT instrument that establish the organization activities involved and how they will share the commercial results (Pimentel, 2010). The findings have a fairly low rate, representing $4.4 \%, 3.6 \%, 4.5 \%$ and $3.4 \%$ between 2011 and 2014 , respectively. In addition, there was no growth over the years, with a decrease in 2012 with 3.6 and in 2014 with $3.4 \%$. This fact can be related to the low index of licensing contracts, to the innovation policy of some universities that do not allow co-ownership, to the low number of projects of R\&D developed in partnership between university-industry.

The contracts for the transfer of biological material are a TT legal instrument to formalize the exchange of biological genetic heritage carried out between RIs based in Brazil and overseas, according to the Convention on Biological Diversity (CBD). It regulates the national sovereignty over biodiversity, the prior informed consent, and the benefit sharing, stemming from the use of genetic heritage (Cruz \& Menuchi, 2007). This type of contract represented a decline over the years, representing $4.7 \%$ in $2011,1.2 \%, 0.3 \%$ and $0.4 \%$ in the following years. This is probably a reflex of the difficult to carry out new contracts of biological material due to the implementation of the CBD in 2010 which established legal marks for the development of biodiversity activities (Brazil, 2015).

These results show that the TT between university-industry is in an embryonic stage in Brazil, requiring research efforts and financial investments to reach the product even if occurred a considerable increase of IP required over the last few years (Póvoa, 2010).
Considering that there are $32 \%$ RIs without TTOs, the rate of IP granted are very low and TT agreements are inexpressive. In this context, it is possible to affirm that the academic research outcomes are not being absorbed in an effective way by the industries, and, as a consequence, they not always go to market.

The stagnation of Brazilian innovation becomes even more dramatic when compared to developed countries such as the United States, UK and South Korea, it evinces an amateur internationalization of the Brazilian IP and an inexpressive relationship between universityindustry for TT processes that affects directly Brazil's (GII, 2015). Notwithstanding, the WIPO report shows that Brazil ranks the $19^{\text {th }}$ with 41.453 patents, behind all BRICS countries, in which China has 875.000, Russia 181.000, South Africa 112.000 and India 42.991 patents (GII, 2015).

\section{Conclusion}

Although there has been a significant investment by the Brazilian government in programs to improve the technological innovation and research activities in universities in recent years, Brazil is in 29th place in the $R \& D$ world investments ranking, with only $1.24 \%$ of national GDP (CNI, 2016). It is possible to affirm that the innovation in Brazil is in an embryonic phase if compared to the world average and it has the worst performance in innovation compared with the BRICS countries, and a much lower position when compared to the best countries in innovation quality like United States, Switzerland, Canada, Germany, France, China.

These investments have resulted in a significant increase of more than $100 \%$ growth in the number of patent applications between 2010 to 2014. However, when comparing applications and IP, it can be seen that Brazil still has a low number of patents granted representing an average of $13.8 \%$ of the requests. This low index can be linked to the INPI's delay in analysing a patent application, which currently takes an average of 12 years, or even the failure to analyse the patent application by the TTOs with regard to patentability requirements: novelty, inventive activity and industrial application. In their majority, the TTOs that are responsible for managing all IP and TT of the RIs still lack infrastructure and personnel with adequate technical capacity.

The number of RIs with technology contracts is also very inexpressive either, accounting for $21 \%$ of the average between 2010 to 2014 . The low percentage of RIs with technology contracts is a reflection of the low index of RIs with IP applications, as well as the reduced number of TT carried out in the country and the low industries financing, considering that most of the financing in Brazil comes from the government. Thus, university-industries partnership is increasingly important to leverage the country's economic development and increase the TT.

The data exposed above show several gaps: the absence of a clear and specific legislation to stimulate the UITT in Brazil , defensive culture of universities regarding to partnerships with industry; low autonomy of TTOs and adequate infrastructure to manage the IP and promote a 
better TT; lack of personnel with low technical capacity in the TTOs to apply the IP protection and conduct economic and technical feasibility studies of patent applications, technological prospecting, innovation management and patent negotiation; the high cost to carry out an international patent application; INPI's delay in examining patent applications.

In this context, the Brazilian universities have a significant number of patent applications, but these technologies do not reach the market, considering that they are not licensed or transferred to any industries. This situation goes against the basic principles that state that all the technologies can only be considered innovations once they go to the market. There is no effectiveness in R\&D investment for innovation if there is no policy aimed at stimulating TT between university-industry.

\section{References}

Ambos, T.C., Mäkelä, K., Birkinshaw, J., d'Este, P. (2008). When does university research get commercialized? Creating ambidexterity in research institutions. Journal of Management Studies, 45, 8, pp. 14241447. doi :http://dx.doi.org/10.1111/j.1467-6486.2008.00804.x

Anatan, L. (2015). Conceptual Issues in University to Industry Knowledge Transfer Studies: A Literature Review. Procedia - Social and Behavioral Sciences, 211, pp. 711-717. doi:http://dx.doi. org/10.1016/j.sbspro.2015.11.090

Audretsch, D.B., Lehmann, E.E., Wright, M. (2014). Technology transfer in a global economy. Journal Technology Transfer, 39, pp. 301312. doi: http://dx.doi.org/10.1007/s10961-012-9283-6

AUTM, 2002. The AUTM Licensing Survey: Fiscal Year 2000. Association of University Technology Managers, Norwalk, CT. Retrieved from: http://www.worldcat.org/title/autm-licensing-survey-fiscalyear-2000/oclc/50194535

Bekkers, R., \& Bodas-Freitas, I. M. (2008). Analysing knowledge transfer channels between universities and industry: To what degree do sectors also matter? Research Policy, 37, 1837-1853. doi:https://doi. org/10.1016/j.respol.2008.07.007

Bessant, J., Rush, H. (1993). Government support of manufacturing innovation: two country level case study. IEEE Transactions of Engineering Management, 40, 1, pp. 79-91. doi: https://doi.org/10.1109/17.206655. Retrieved from:https://ieeexplore.ieee.org/document/206655/

Bodas-Freitas, I. M., Geuna, A., \& Rossi, F. (2011). Patterns of Collaborations between Regional Firms and Universities: Evidence from the Piedmont region in Italy. Collaborations? LEI \& BRICK Working Paper 05/2011, Department of Economics, University of Torino, pp 1-33. Retrieved from: https://econpapers.repec.org/paper/utolabeco/201105.htm

Bölling, M., \& Eriksson, Y. (2016). Collaboration with society: The future role of universities? Identifying challenges for evaluation. Research evaluation, 25(2), 209-218. doi: https://doi.org/10.1093/reseval/rvv043
Bozeman, B. (2000). Technology transfer and public policy: a review of research and theory. Research policy, 29(4), 627-655. doi:https:// doi.org/10.1016/S0048-7333(99)00093-1

Brazil. Brazilian Institute of Geography and Statistics (IBGE). Demographic Census 2010. Retrieved from: https://ww2.ibge.gov.br/home/ estatistica/populacao/censo2010/default.shtm

Brazil. Federal Law n. 10.973, dated december 2, 2004. Provides incentives for innovation and scientific and technological research in the productive environment and other measures. Presidency of the Republico f Brazil. Brasilia, DF. Retrieved from:http://www.planalto.gov. br/ccivil_03/_ato2004-2006/2004/lei/110.973.htm

Brazil. Ministry of Science, Technology and Innovation (MCTI). Science, Technology and Innovation for National Development. National Strategy for Science Technology and Innovation 2016 2019. Brasília, 2016. Retrieved from:http://www.propesq.unir.br/ uploads/76767676/arquivos/Estrat_gia_Nacional_de_Ci_ncia__ Tecnologia_e_Inova_o_2016_2019_1248378469.pdf

Bukała, A. (2008). What innovation and technology transfer really mean?. Journal of Automation Mobile Robotics and Intelligent Systems, 2, 74-76. Retrieved from:http://yadda.icm.edu.pl/baztech/element/bwmeta1.element.baztech-article-BUJ5-0020-0010

Burhanuddin, M.A., Arif, F., Azizah, V., Prabuwono, A.S. (2009).

Barriers and challenges for technology transfer in Malaysian small and medium industries. In Information Management and Engineering, 2009. ICIME'09. International Conference on, pp. 258-261. doi:10.1109/ICIME.2009.39. Retrieved from:https://ieeexplore.ieee. org/document/5077038/

Casali, Giovana F. Rossi, Silva, Orlando Monteiro da, \& Carvalho, Fátima M. A.. (2010). Regional innovation system: study of Brazilian regions. Journal of Contemporary Economics, 14(3), 515-550. doi:http:// dx.doi.org/10.1590/S1415-98482010000300004

Chapple, W., Lockett, A., Siegel, D., Wright, M. (2005). Assessing the relative performance of U.K. University technology transfer offices: Parametric and non-parametric evidence. Research Policy, 34, 3, pp. 369-384. doi:http://dx.doi.org/10.1016/j.respol.2005.01.007

Clarysse, B., Tartari, V., \& Salter, A. (2011). The impact of entrepreneurial capacity, experience and organizational support on academic entrepreneurship. Research Policy, 40, 1084-1093. doi:https://doi. org/10.1016/j.respol.2011.05.010

Crespi, G. A., Geuna, A., \& Nesta, L. (2007). The mobility of university inventors in Europe. The Journal of Technology Transfer, 32(3), 195215. doi: https://doi.org/10.1007/s10961-006-9012-0

Crespi, G., D’Este, P., Fontana, R., \& Geuna, A. (2011). The impact of academic patenting on university research and its transfer. Research policy, 40(1), 55-68. doi: https://doi.org/10.1016/j.respol.2010.09.010 
Cruz, G., \& Bezerra, N. V. S. (2017). Innovation in renewable energies: reflections and study of technological prospection. SENAC Technical Bulletin, 43(1). Retrieved from: http://www.bts.senac.br/index. php/bts/article/view/408/374

Cruz, G; Menuchi, L. N. S. (2016), Technology transfer and biodiversity: Analysis of Brazilian legislation through the access and benefits sharing perspective. International Journal of Recent Advances in Multidisciplinary Research, v. 4, n. 1, 2017. Retrieved from: https://www. researchgate.net/profile/Gustavo_Da_Cruz/publication/313649984_ Technology_Transfer_and_Biodiversity_Analiysis_of_Brazilian_Legislation_throught_the_acess_and_benefits_sharing_perspective/ links/58a186edaca272046aad8e52/Technology-Transfer-and-Bi

Dooley, L., \& Kirk, D. (2007). University-industry collaboration: Gra$\mathrm{fting}$ the entrepreneurial paradigm onto academic structures. European Journal of Innovation Management, 10(3), 316-332. doi: https:// doi.org/10.1108/14601060710776734

Dutta, S., Lanvin, B., \& Wunsch-Vincent, S. (2015). The Global Innovation Index 2015 (GII). Effective Innovation Policies for Development, Cornell University, INSEAD, the World Intellectual Property Organization (WIPO), Fontainebleau, Ithaca, and Geneva. Retrieved from: https://ideas.repec.org/p/ess/wpaper/id7491.html

Etzkowitz, H. (1998). The norms of entrepreneurial science: cognitive effects of the new university-industry linkages. Research Policy, 27, pp. 823-833.doi: http://dx.doi.org/10.1016/S0048-7333(98)00093-6

Etzkowitz, H. (2003). Research groups as 'quasi-firms': the invention of the entrepreneurial university. Research Policy, 32, 109-121. doi: https://doi.org/10.1016/S0048-7333(02)00009-4

Etzkowitz, H., Leydesdorff, L. (1998). The Triple Helix as a Model for Innovation Studies. Science \& Public Policy, 25, 3, pp. 195-203.doi: http://dx.doi.org/10.1093/spp/25.3.195

Etzkowitz, H., Leydesdorff, L. (1999). The Future Location of Research and Technology Transfer, Journal of Technology Transfer, 24, pp. 111-123. doi: http://dx.doi.org/10.1023/A:1007807302841

Etzkowitz, H., Leydesdorff, L. (2000). The dynamics of innovation: from National Systems and "Mode 2" to a Triple Helix of universityindustry-government relations. Research policy, 29, 2, 109-123. doi: http://dx.doi.org/10.1016/S0048-7333(99)00055-4

Fontana, R., Geuna, A., \& Matt, M. (2006). Factors affecting university-industry $\mathrm{R} \& \mathrm{D}$ projects: The importance of searching, screening and signalling. Research policy, 35(2), 309-323. doi: https://doi. org/10.1016/j.respol.2005.12.001

Fujino, A., \& Stal, E. (2007). Management of intellectual property in the Brazilian public university: guidelines for licensing and commercialization. Business Review, 12(1), 104-120. doi: https://doi. org/10.7867/1980-4431.2007v12n1p104-120
Geisler, E., Turchetti, G. (2015). Commercialization of Technological Innovations: The Effects of Internal Entrepreneurs and Managerial and Cultural Factors on Public-Private Inter-Organizational Cooperation. International Journal of Innovation and Technology Management, 12, 02, 1550009. doi:http://dx.doi.org/10.1142/ S0219877015500091

Gervais, M.J., Marion, C., Dagenais, C., Chiocchio, F., Houlfort, N. (2016). Dealing with the complexity of evaluating knowledge transfer and innovation performance: Evidence from Chinese firms. Technological Forecasting \& Social Change, 73, pp. 666-678. doi:https://doi. org/10.1093/reseval/rvv034

Geuna, A., \& Nesta, L. J. (2006). University patenting and its effects on academic research: The emerging European evidence. Research policy, 35(6), 790-807. doi: https://doi.org/10.1016/j.respol.2006.04.005

Geuna, A., Muscio, A. (2009). The Governance of University Knowledge Transfer: A Critical Review of the Literature. Minerva, March, pp. 93-114. doi: http://dx.doi.org/10.1007/s11024-009-9118-2

Greene, K. (1994). Technology and innovation in context: the Roman background to mediaeval and later development. Journal of Roman Archaeology, 7, pp. 22-33. doi: https://doi.org/10.1017/ S1047759400012484

Guan, J.C., Mok, C.K., Yam, R.C.M., Chin, K.S.M., Pun, K.F. (2006). Technology transfer and innovation performance: Evidence from Chinese firms. Technological Forecasting \& Social Change, 73, pp. 666678. doi: http://dx.doi.org/10.1016/j.techfore.2005.05.009

Günsel, A. (2015). Research on Effectiveness of Technology Transfer from a Knowledge Based Perspective. Procedia - Social and Behavioral Sciences, 207, 777-785. doi: https://doi.org/10.1016/j.sbspro.2015.10.165

Hertzfeld, H. R., Link, A. N., \& Vonortas, N. S. (2006). Intellectual property protection mechanisms in research partnerships. Research Policy, 35(6), 825-838. doi: https://doi.org/10.1016/j.respol.2006.04.006

Holt, R. (1990). Milling Technology in the Middle Ages: The Direction of Recent Research Journal. Industrial Archaeology Review, 13, pp.1-25. doi: http://dx.doi.org/10.1179/iar.1990.13.1.50

INPI. National Institute of Industrial Property (2016). Technology transfer. Retrieved from: http://www.inpi.gov.br/menu-servicos/ transferencia.

Jafari, M., Akhavan, P., \& Rafiei, A. (2014). Technology Transfer Effectiveness in Knowledge-Based Centers Providing a Model Based on Knowledge Management. International Journal of Scientific Knowledge. Retrieved from:https://ssrn.com/abstract=2424197

Kenney, M., \& Mowery, D. C. (Eds.). (2014). Public universities and regional growth: Insights from the University of California. Stanford University Press. 
Kim, Y., \& Vonortas, N. S. (2006). Technology licensing partners. Journal of Economics and Business, 58(4), 273-289. doi: https:// doi.org/10.1016/j.jeconbus.2005.10.004

Link, A. N., Siegel, D. S., \& Bozeman, B. (2007). An empirical analysis of the propensity of academics to engage in informal university technology transfer. Industrial and Corporate Change, 16(4), 1-15. doi:https://doi.org/10.1093/icc/dtm020

Macho-Stadler, I., Pérez-Castrillo, D., \& Veugelers, R. (2007). Licensing of university inventions: The role of a technology transfer office. International Journal of Industrial Organization, 25(3), 483-510. doi: https://doi.org/10.1016/j.ijindorg.2006.06.001

Markman, G. D., Siegel, D. S., \& Wright, M. (2008). Research and technology commercialization. Journal of Management Studies, 45(8), 1401-1423. doi: https://doi.org/10.1111/j.1467-6486.2008.00803.x

Markman, G.D., Gianiodis, P.T., Phan, P.H., Balkin, D.B. (2005). Innovation speed: Transferring university technology to market. Research Policy, 34, pp. 1058-1075. doi:http://dx.doi.org/10.1016/j.respol.2005.05.007

Mattila, M., \& Lehtimaki, H. (2016). Networks in Technology Commercialization. South Asian Journal of Business and Management Cases, 5(1), 43-54. doi: http://dx.doi.org/10.1177/2277977916634235

Mazzucato, M., \& Penna, C. (2016). The Brazilian innovation system: a mission-oriented policy proposal. Retrieved from: https://www.cgee. org.br/documents/10195/1774546/The_Brazilian_Innovation_System-CGEE-MazzucatoandPenna-FullReport.pdf

Molas-Gallart, J., Castro-Martínez, E. (2007). Ambiguity and conflict in the development of 'Third Mission'indicators. Research Evaluation, 16, 4, pp. 321-330. doi: https://doi.org/10.3152/095820207X263592:

Mowery, D. C., \& Ziedonis, A. Z. (2015). Markets versus spillovers in outflows of university research. Research Policy, 44, 50-66. doi: https://doi.org/10.1016/j.respol.2014.07.019

Muscio, A., Quaglione, D., \& Vallanti, G. (2014). University regulation and university-industry interaction: a performance analysis of Italian academic departments. Industrial and Corporate Change Advance, 1, 1-33. doi: https://doi.org/10.1093/icc/dtu022

National Confederation of Industry, Social Service of Industry, National Service of Industrial Learning, Brazilian Service of Support to Micro and Small Companies (CNI, 2016.).Performance of Brazil in the global index of innovation 2011-2016. Brasilia, DF. Retrieved from:http:// www.ipdeletron.org.br/wwwroot/pdf-publicacoes/34/desempenho_ do_brasil_no_indice_global_de_inovacao_2011_2016.pdf

OECD. (2007). Higher education and regions: Globally competitive, locally engaged. Retrieved from: http://www.oecd.org/education/imhe/ highereducationandregionsgloballycompetitivelocallyengaged.htm
Pausits, A. (2015). The Knowledge Society and Diversification of Higher Education: From the Social: Contract to the Mission of Universities. In: Curaj, A. et al. (Org.) The European Higher Education Area: Between Critical Reflections and Future Policies. Springer. doi: http://dx.doi.org/10.1007/978-3-319-20877-0_18

Perkmann, M., \& Schildt, H. (2015). Open data partnerships between firms and universities: The role of boundary organizations. Research Policy, 44(5), 1133-1143. doi: https://doi.org/10.1016/j.respol.2014.12.006

Perkmann, M., Fini, R., Ross, J., Salter, A., Silvestri, C., Tartari, V. (2015). Accounting for universities' impact: Using augmented data to measure academic engagement and commercialization by academic scientists. Research Evaluation, 24, 4, pp. 380-391. doi: http://dx.doi. org/10.1093/reseval/rvv020

Perkmann, M., Tartari, V., McKelvey, M., Autio, E., Broström, A., D'Este, P., Krabel, S. (2013). Academic engagement and commercialisation: A review of the literature on university-industry relations. Research policy, 42, 2, pp. 423-442. doi http://dx.doi.org/10.1016/j.respol.2012.09.007

Phan, P. H., \& Siegel, D. S. (2006). The effectiveness of university technology transfer. Foundations and Trends ${ }^{\circledast}$ in Entrepreneurship, 2(2), 77-144. doi: https://doi.org/10.1561/0300000006

Piirainen, K. A., Andersen, P. D., \& Andersen, A. D. (2016). Foresight and the third mission of universities: The case for innovation system foresight. Foresight, 8(1), 1-34. doi: https://doi.org/10.1108/ fs-04-2014-0026

Pimentel, L. O. (2010). Basic manual of R\&D partnership agreements: legal aspects. EDIPUCRS. Retrieved from: http://www.fortec.org.br/ documentos/MANUAL_BASICO_ACORDOS.pdf

Póvoa, L. M. C., \& Rapini, M. S. (2010). Technology transfer from universities and public research institutes to firms in Brazil: what is transferred and how the transfer is carried out. Science and Public Policy, 37(2), 147-159. doi: https://doi.org/10.3152/030234210x496619

Ramirez, P., Love, J. H., \& Vahter, P. (2013). Industry-academic links: A new phase in Ireland's FDI-led industrialisation strategy. European Urban and Regional Studies, 23(2), 167-181. doi: https://doi. org/10.1177/0969776413493632

Ranga, M., Etzkowitz, H. (2013). Triple Helix systems: an analytical framework for innovation policy and practice in the Knowledge Society. Industry \& Higher Education, 27, 3, pp. 237-262. doi: http://dx.doi.org/10.5367/ihe.2013.0165

Ranga, M., Temel, S., Murat Ar, I., Yesilay, R.B., Sukan, F.V. (2016). Building Technology Transfer Capacity in Turkish Universities: a critical analysis. European Journal of Education, 51, 1, pp. 09-106. doi: http://dx.doi.org/10.1111/ejed.12164 
Reddy, M., Zhao, l. (1990). International technology transfer: A review. Research Policy, 19, 4, pp. 285-307. doi: http://dx.doi. org/10.1016/0048-7333(90)90015-X

Schaeffer, P. R., Dullius, A. C., Maldonado, R., \& Zawislak, P. A. (2015). Types of university-industry interaction: A new approach to bridge the gap between universities and industries. XVI Congresso Latino-Iberoamericano de Gestão Tecnologia. ALETC, Porto Alegre, Brasil. Retrieved from: http://altec2015.nitec.co/altec/papers/595.pdf

Shane, S. (2002). Selling University Technology: Patterns from MIT. Management Science, 48(1), 122-137. doi: https://doi.org/10.1287/ mnsc.48.1.122.14281

Shane, S., \& Venkataraman, S. (2007). The Promise of Entrepreneurship as a Field of Research. Entrepreneurship, 171-184. doi: https://doi. org/10.1007/978-3-540-48543-8_8

Siegel, D. S., Veugelers, R., \& Wright, M. (2007). Technology transfer offices and commercialization of university intellectual property: Performance and policy implications. Oxford Review of Economic Policy, 23(4), 640-660. doi: https://doi.org/10.1093/oxrep/grm036

Siegel, D. S., Waldman, D. A., Atwater, L. E., \& Link, A. N. (2003). Commercial knowledge transfers from universities to firms: improving the effectiveness of university-industry collaboration. The Journal of High Technology Management Research, 14(1), 111-133. doi: http://dx.doi.org/10.1016/S0048-7333(01)00196-2

Taheri, M., Geenhuizen, M. (2016). Teams' boundary-spanning capacity at university: Performance of technology projects in commercialization. Technological Forecasting \& Social Change, in press. doi: http://dx.doi.org/10.1016/j.techfore.2016.06.003

Thursby, J. G., Jensen, R., \& Thursby, M. C. (2001). Objectives, characteristics and outcomes of university licensing: A survey of major US universities. The journal of Technology transfer, 26, 1-2, pp. 59-72. doi: https://doi.org/10.1023/A:1007884111883
Torkomian, A. L. V. (2009). Overview of the nuclei of technological innovation in Brazil. Technology transfer. Campinas: Komedi, 21-37. Retrived from: https://www.inova.unicamp.br/sites/default/files/documents/Livro\%20Transferencia\%20de\%20tecnologia_0.pdf

Verhoeven, D., Bakker, J., \& Veugelers, R. (2016). Measuring technological novelty with patent-based indicators. Research Policy, 45(3), 707-723. doi: http://dx.doi.org/10.1016/j.respol.2015.11.010

Wahab, S.A., Rose, R.C., Wati, O.S.I. (2012). Defining the Concepts of Technology and Technology Transfer: A Literature Analysis. International Business Research, 5, 1, pp. 61-71. doi: http://dx.doi. org/10.5539/ibr.v5n1p61

Wallin, J., Isaksson, O., Larsson, A., \& Elfström, B. O. (2014). Bridging the gap between university and industry: three mechanisms for innovation efficiency. International Journal of Innovation and Technology Management, 11(01), 1440005. doi: https://doi.org/10.1142/ S0219877014400057

Walter, S. G., Schmidt, A., \& Walter, A. (2016). Patenting rationales of academic entrepreneurs in weak and strong organizational regimes. Research Policy, 45(2), 533-545. doi: https://doi.org/10.1016/j. respol.2015.11.008

Warren, L., Kitagawa, F., \& Eatough, M. (2010). Developing the Knowledge Economy through University Linkages. The International Journal of Entrepreneurship and Innovation, 11(4), 293-306. doi: https://doi.org/10.5367/ijei.2010.0005

Wright, M., Birley, S., Mosey, S. (2004). Entrepreneurship and University Technology Transfer. Journal of Technology Transfer, 29, pp. 235-246. doi: http://dx.doi.org/10.1023/B:JOTT.0000034121.02507.f3

Zhao, L., Reisman, A. (1992). Toward Meta Research on Technology Transfer. IEEE Transactions on Engineering Management, 39, 1, pp. 13-21. doi:http://dx.doi.org/10.1109/17.119659. Retrieved from: https://ieeexplore.ieee.org/document/119659/ 
